\title{
SELECTION METHOD AND PERFORMANCE OF FACULTY MEMBERS: EVIDENCES FROM PUBLIC SECTOR BUSINESS INSTITUTIONS
}

\author{
Noor Jehan \\ Assistant Professor Abdul Wali Khan University Mardan \\ Naveed Hussain \\ Sydney Police Australia \\ Salma Khan \\ Bacha Khan University Charsadda Pakistan \\ Gohar Saeed \\ Field research specialist Pakistan Academy for Rural Development
}

\begin{abstract}
Purpose: The main purpose of the study is to compare the selection criteria of the faculty members in order to find its effect on the performance of persons selected. The main idea was that the employee delivery of work is linked with the way they are chosen.

Methodology /Sample: The research focused on four business institutes of Peshawar. The Data was collected through structured interviews from the heads and registrar while questionnaires from students of the same organization.

Findings: The study found that there is a similarity in the combination of the faculty while difference in selection and students' satisfaction level. It was concluded that selection process is closely linked to the performance of teachers.

Practical Implications: The findings imply that selection process has lasting effects on the delivery of service and it must be dealt with utmost care. The first step in inducting employee necessitates equality of procedure.
\end{abstract}

Key Words: Selection Criteria, Likert scale, Kruskal Wallis H-Test, Teacher Performance Jel Classification: M54, M51, M10

*The material presented by the author does not necessarily portray the view point of the editors and the management of the Institute of Business \& Technology - IBT

1. Noor Jehan : noorejaan82@yahoo.com

CIBT-JBS is published by the Institute of Business \& Technology - IBT

Main Ibrahim Hydri Road, Korangi Creek, Karachi-75190, Pakistan 


\section{INTRODUCTION}

\subsection{Background of the Study}

As the number of professional institutes increases, the need for professionalism increases as well. The Business education institutes has been increased with a very rapid speed which has challenged the academics, the administration and Human Resource to cope it with profound care especially selection of faculty.

Selection is sometime done carelessly and the result could be a harsh reality. It can seriously effect and it does affect stake holders. It may shake their confidence into the selection authority and the one who is selected. If accepted methodology is followed, that which is applied in maximum situation, can be a mean towards their (stakeholder's) expectations. Teaching at every level has a direct and long lasting impact on students and their personal life including their social activities. Pakistan, a mixed economy, a mixed culture in education and a mixture of teaching and teacher's selection, is seriously engulfed by the dissatisfaction of almost all concerned. The bosses are mostly autocratic and there is a huge gap between depending and dependant beings.

Decision making is one of the most principal activities in management and the end point of every process. But if it is not considered to decide on some grounds and inculcate our own personal views into the process, the results could be alarming. Such could harm our National strength and our collective purpose. Education in general and higher education institutes in special is seriously affected by this carelessness. The long lasting impacts could seriously dissatisfy students and their confidence in them.

The excellence of teaching matters for education though there has been no close link found between teachers' own qualification with the student achievement. (Rockoff,2003).

Hanushek (1986) had provided an account of 147 such studies in which the focus is on a relation between students' performance and teachers characteristics. In most of the cases which regarded teacher education and teacher experience, the estimated coefficients are statistically insignificant. So the method for selecting teachers becomes a matter of research.

Classroom is suitable for researching the intake of whether students are receiving enough content. Pennington (1989) focused on the result oriented teaching. Research has emphasized on teacher reasoning power, his/her judgment ability, and knowledge for an exemplary teacher. Behavior is not given much consideration (Fawns and Nance, 1993).

HR practices have been the point of discussion in many studies, focusing on its relation to employee and organizational performances (Tzafrir 2005; Tessema and Soeters, 2006; Kashif, Abbas \& Shahzad 2010, Shahzad, Bashir \& Ramay 2008).

Teacher's attraction, development and retention are considered to be the major responsibility on the part of administration of higher education institutes. It is essential for any education system to have good teachers. But the extent of infrastructural support is a question worked out by Qaisar (2011) in the context of private universities. Shehzad, Bashir \& Ramay (2008) have proposed that HR practices have relation with employee performance. There are eight such practices of which recruitment and selection is a key one (Teseema \& Soeters, 2006; Huselid, 1995). 


\subsection{Selection and Recruitment}

William et al. (2000) have defined selection as a process sequencing specific steps directed at the selection of recruit. The starting point is the apply by recruit and ending when someone suitable is hired.

Similarly recruitment involves finding of facts and attraction of able people for the job. It is started when people suitable for job are found and with the submission of application, the process ends. It results into a pool of applicant which is the step for selection. (Buford et al. 2000)

\subsubsection{Employee Selection}

It is critical towards the success of the organization to have effective selection of employees. The performance of a job is detrimental to the affectivity of an organization.

It is the effectiveness of selection in fact which increases the probability of good delivery of work by employees and hence the possession of needed KSAs. Not only this, it is a base for other related practices as well like goal setting and design of job, compensation plans; which is a motivation for better work (Gate Wood and H.S. Field, 2001).

Human resource management is directed at the improvement of the productivity of individuals in an ethical, strategic and socially responsible way. This is a guide for personnel management- fining of facts for the attraction of incumbents. Competition is at its peak. To remain in, the stakeholders needs need to be met which is really a challenge. And human are the resource for which organizations are competing the most for skill are mostly short and through skilled workers, organizations are able to remain in competition for satisfying customer needs in terms of products and services. Recruitment is such a step which helps in attracting people suiting our requirements serving as buffer to coordinate the planning and actual selection (Wood and Field, 2001).

But problems arise at this stage affecting competitive edge of organization and its performance and a formal structure should be followed for the purpose to help take effective selection (Adem and Esra, 2006). Technology can be very helpful $\mathrm{n}$ this regard for screening and collection of application i.e. electronic recruitment (Hogler et al. 1998). Small businesses are found to follow more systematic selection (Lindner and Zoller, 1996).

In this research student's satisfaction in terms of teaching effectiveness is addressed. Linkages are made with the selection and recruitment process as it was evident that $52 \%$ of its faculty is on contract or visiting basis.

\subsection{Study Objective}

This study aimed at highlighting and comparing the selection criteria and methods in all four sampled business educational institutes and hereby checking the difference in faculty member's performance based on student's satisfaction.

\subsection{Significance of the Study}

The study embodies its significance in its objectives. It is helpful in correcting recruitment and selection shortfalls and check what is resulted if right person is not at right job. This study is an attempt to show the importance of proper selection and the satisfaction 
of related dependants in Higher Education Institutes and hence give an eye opener to the administration, academia and general public.

\section{RESEARCH METHODOLOGY}

There were four prominent business institutions in Peshawar. They are institute of business and Management Sciences, the Quid-e-Azam College of Commerce, Institute of Management Studies and Institute of Management Sciences. From these four strata were drawn on the basis of five percent sample of the whole population. But the number of students in Quaid e Azam college was low, so we selected ten percent. Another sample was of administrative staff of all these colleges. There were five likert item included for noting the responses regarding teachers' performance. Likert summation scale provided the final sum of checked item as is given in table no.1.

\subsubsection{TEST STATISTICS}

As per the requirements of the study the The Kruskel-Wallis $\mathrm{H}$ test.This test was used for differences among students' satisfaction of teachers. As the selection processes are different in these institutes, a difference in satisfaction is assumed to show the different effect of the teachers hired.

The formula is

$$
H=\frac{12}{N(N+1)} \sum\left(\frac{\sum R_{i}{ }^{2}}{N i}\right)-[3(N+1)]
$$

With k-1 degree of freedom

Where

$\mathrm{N}$ refers to total number of respondents in $\mathrm{k}$ samples

$\mathrm{Ni}$ refers to number of respondents in ith sample

Ri refers to summation of ranks for ith sample

$\mathrm{H}$ value equals chi-square having k-1 degrees of freedom whereas it is just about chi square (Champion, 1981)

\subsubsection{Study Variables}

Following are the major variables for recruitment and selection. (Werther and Davis, $5^{\text {th }}$ edition). These are considered standard format of selection in Pakistan.

1. Advertisement

2. Initial short listing

3. Screening test

4. Short listing

5. Final interview

6. Selection

7. Probation

8. Permanent status 
If all the steps are followed for selecting an employee then it constitutes a standard selection process. And if the process is not in the given order then it is nonstandard process. Similarly the variables for faculty performance; Subject command, Class control, students' satisfaction, students results, teacher punctuality and commitment are some of the various benchmarks for better teaching as given by Higher Education Commission of Pakistan are included in the present case. The model is shown below for a graphic representation of the relationship between variables. It shows that a non-standard selection process effects student satisfaction from teaching and hence the performance of the teacher is affected.

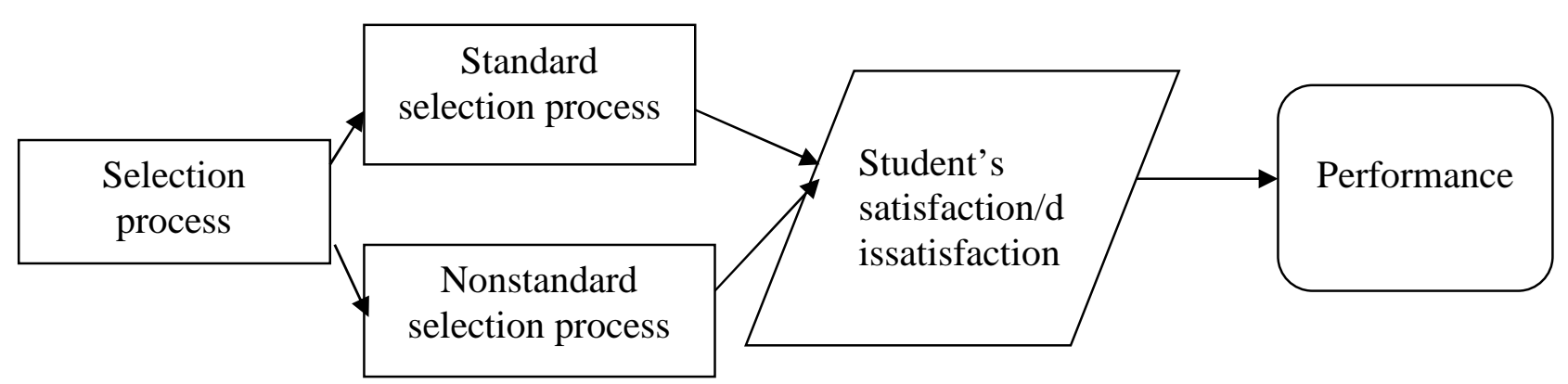

\section{RESULTS AND DISCUSSIONS}

In order to know the process of selection, the key administrative personnel were interviewed. The results showed different methods followed by these institutions. Quaid e Azam College and institute of management studies are provided faculty by the University of Peshawar which follow formal procedure. The focus is given to screening test and presentation skills. There is no initial interview. Information is disseminated through telephone call, daily newspaper, electronic mails and post. They also make internal advertisement. The selectee has to undergo a year of probation in most cases. The Institute of business and management has no electronic or print media advertisement. They have no short listing as such and there is one and only interview. In case of Institute of Management Sciences, the jobs are advertized in almost all means of communication. Short listing is done keeping $\mathrm{n}$ mind the KSAs related to the job. There is an initial interview after the screening test and then a final interview. Beside other means of communication Institute of Management Sciences uses its website for information sharing. The probation period is one year and then the candidate is given permanent status.

There was descriptive analysis based comparison. It was found that the student of IM Studies have rated their faculty better with mean points of 39.33. The second rated was QCC with 37 mean whereas Sciences as 36.72 while IBMS was rated with 31.25 points. In terms of variation, the lowest was in Institute of management studies responses with 0.4045 standard error of mean. The second best reponse was in case of IBMS ( $\mathrm{S} . \mathrm{E}=.4833$ ). Institute of Management Sciences has much variation with S.E. of mean 677 followed by QCC has witnessed much variation $\left(S_{\bar{x}}=1.5165\right)$.

The coefficient of variation shown that there was more consistency in case of IM Studies with coefficient of variation 10.29 followed by CV of 18.46 for IM Sciences and IBMS (CV of 21.82). QCC has been the least consistent with CV of 26.56. 
The result showed that the students of IM Studies rated it the best. With maximum mean, much smaller standard of mean and CV. QCC had received better rated but it was less in consistency. IBMS was rated low by its students but the rating was consistent compared to IM Sciences and QCC. Although IM Sciences was given higher rank than IBMS it was less consistent. The test result was 109. 648 of chi square with significance at $5 \%$ level. It is evident that there is present a significant difference between the students' satisfaction for the sampled institutes. Not only this, the selection process also vary to a greater extent

\section{CONCLUSIONS}

The results revealed difference of selection process in all these business colleges. Students' satisfaction was also found significantly different. But the faculty combination was almost similar. The faculty consist of permanent, contract and visiting teachers. The

The results provide evidence that difference in Selection Process or Criteria does result in different levels of student's satisfaction. We can conclude that Selection Process or Criteria effects teacher's performance, measured by the students' satisfaction level.

\section{RECOMMENDATIONS}

Following are the main recommendations given.

1. There should be a uniform approach towards Selection Process in these Institutions as well as other Organizations.

2. Students and teachers are the main elements in an Educational Institute, they must be dealt with proper care.

3. Other research studies should be made in this regard.

\section{REFERENCES}

Adem, G., \& E. Kahya. 2006. A fuzzy model for competency-based employee evaluation and selection. Fuzzy Sets $22:(1-2) 107-114$

Buford, J.A., A.G. Bedian and J.R. Linder. 1995.Management in Extension ( $3^{\text {rd }}$ edition) Columbus, Ohio: Ohio State University Extension.

Champion. J. D. 1981. Basic statistic for social Research, New York: Macmillan Publishing Co. $2^{\text {nd }}$ Ed. pp $(283,286)$.

Gatewood, R. D., \& H. S. Field. 2001. "Human Resource Selection”. 5th ed. Fort Worth, TX: Dryden Press. pp. 639-651.

Hogler. L.R., H .Christine, \& B.Carol .1998. Internet recruiting and employment discrimination: a legal perspective: Human Reso. Manag. Revi. 8(2): 149-164.

Hanushek, Eric A. 1986. "The Economics of Schooling: Production and Efficiency in Public

Schools," Journal of Economic Literature, September, 1986.

Huselid, M. A. 1995. The impact of human resource management practices on turnover, productivity and corporate financial performance, Academy of Management Journal, 38(3), 635-672.

Lindner, J. R., \&, C. Zoller 1996. "Recruiting Employees for Small Businesses: A little planning goes a long way, Extension Fact Sheet: Small Business Series”, Columbus, Ohio: Ohio State University Extension. 23(3): 43-46

Qaisar, 2011. Effects of HR practices on performance of university teachers (A survey on Pakistani private universities) 
Posted: Jan 20,2011 http://www.articlesbase.com/human-resources-articles/effects-of-hrpractices-on-performance-of-university-teachers-a-survey-on-pakistani-privateuniversities-4074709.html\#ixzz1q0xy0XbU

Rockoff, J.E.2003. The impact of individual teachers on students' achievements; evidence from panel data. A project submitted to Harvard university.

Shahzad, K., S. Bashir and I.M. Ramay. 2008. Impact of HR Practices on Perceived Performance of University Teachers in Pakistan, International Review of Business Research Papers Vol. 4 No.2 March 2008 Pp.302-315.

Tessema, M. and Soeters, J. 2006. Challenges and prospects of HRM in developing countries: testing the HRM-performance link in Eritrean civil service, International Journal of Human Resource Management, 17(1), 86-105.

William, B. R. Werther, J. R. K. Davis. 2000. HR and Personnel Management. ${ }^{\text {th }}$ Ed. pp.120-127.

\section{Appendix}

Table no. 2

Employee Status

\begin{tabular}{|l|l|l|l|l|l|l|l|l|}
\hline Institutes & \multicolumn{2}{l}{ Permanent } & \multicolumn{2}{l|}{ Contract } & \multicolumn{2}{l|}{ Visiting } & \multicolumn{2}{l|}{ Total } \\
\hline IM Studies & 21 & $65.6 \%$ & 1 & $3 \%$ & 10 & $31 \%$ & 32 & $100 \%$ \\
\hline QCC & 4 & $50 \%$ & 4 & $50 \%$ & 0 & $0 \%$ & 8 & $100 \%$ \\
\hline IM Sciences & 4 & $10.52 \%$ & 25 & $65.78 \%$ & 9 & $23.69 \%$ & 38 & $100 \%$ \\
\hline IBMS & 1 & $1 \%$ & 61 & $63 \%$ & 35 & $36 \%$ & 97 & $100 \%$ \\
\hline Total & 30 & $17 \%$ & 91 & $52 \%$ & 54 & $60 \%$ & 175 & $100 \%$ \\
\hline
\end{tabular}

Source:survey

Table no. 3 Comparison of Samples on the basis of Statistics

\begin{tabular}{|l|l|l|l|l|l|}
\hline \multicolumn{2}{|l|}{} & IBMS/CS & IM Studies & IM Sciences & $\begin{array}{l}\text { Quid-e-Azam College } \\
\text { of Commerce }\end{array}$ \\
\hline Mean & & 31.2550 & 39.3300 & 36.7200 & 37.0000 \\
\hline $\begin{array}{l}\text { Std. Error of } \\
\text { Mean }\end{array}$ & .4822 & .4045 & .6779 & 1.5165 \\
\hline Std. Deviation & 6.8200 & 4.0453 & 6.7795 & 9.8278 \\
\hline Variance & 46.5125 & 16.3647 & 45.9612 & 96.5854 \\
\hline $\begin{array}{l}\text { Coefficient of } \\
\text { variance (CV) }\end{array}$ & 21.82051 & 10.28477 & 18.46269 & 26.56162 \\
\hline
\end{tabular}

Source: survey 
Kruskal - Wallis H Test for finding the difference in Student's satisfaction

Table no.4 Test Statistics

\begin{tabular}{|l|l|}
\hline & Performance \\
\hline Chi Square & 109.648 \\
\hline Degrees of freedom & 3 \\
\hline Asymp. Sig & .000 \\
\hline
\end{tabular}

Source: calculation of survey data 